\title{
EFFECTS OF GOVERNMENT PRICE INTERVENTION POLICY ON THE COMPETTITIVENESS OF THAI RICE EXPORT
}

\author{
Saranya Raksond, Ph.D, Mahasarakham Business School, Mahasarakham University, Thailand \\ Prawpalilan Janposri, Mahasarakham Business School, Mahasarakham University, Thailand
}

dx.doi.org/10.18374/RBR-14-1.10

\begin{abstract}
This research aims to investigate the effects of government price intervention policy on the competitiveness of Thai rice export in ASEAN. The research was conducted by using secondary data, time series data from 1997 - 2012. The research found that Thailand still in the situation that highly competitiveness in world rice export. In addition, the research also shown that the factors affecting competitiveness of Thai rice export in ASEAN were ASEAN GDP, exchange rate, and the level of government price intervention. This research could be used as a guideline for government to setting the competitive policy and price intervention policy in the future.
\end{abstract}

Keywords: Thai Rice Export, Competitiveness, ASEAN, Government, Price Intervention 